$$
\begin{array}{ll}
\text { Research Square } & \text { Preprints are preliminary reports that have not undergone peer review. } \\
\text { They should not be considered conclusive, used to inform clinical practice, } \\
\text { or referenced by the media as validated information. }
\end{array}
$$

\title{
Transforaminal and Posterior Lumbar Interbody Fusion for Llumbar Degenerative Diseases, which one is better: A meta-analysis Through a Ggrade Analysis of Evidence
}

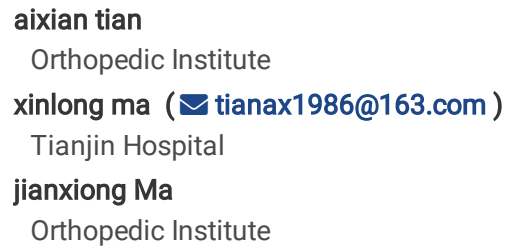

\section{Research article}

Keywords: posterior lumbar interbody fusion (PLIF), transforaminal lumbar interbody fusion (TLIF), lumbar degenerative diseases, meta-analysis Posted Date: November 1st, 2021

DOI: https://doi.org/10.21203/rs.3.rs-910433/v1

License: (c) (1) This work is licensed under a Creative Commons Attribution 4.0 International License. Read Full License 


\section{Abstract}

Background

To explore the efficacy and safety between posterior lumbar interbody fusion (PLIF) and transforaminal lumbar interbody fusion (TLIF) in the treatment of lumbar degenerative diseases.

Methods

We searched the literature in Pubmed, Embase, Cochrane Library and Web of Science. The index words were posterior lumbar interbody fusion, PLIF, transforaminal lumbar interbody fusion, TLIF, lumbar interbody fusion, spinal fusion, degenerative disc disease and lumbar degenerative diseases. Primary outcomes were fusion rate and complications. Secondary outcomes were visual analog scale ( $\triangle$ VAS), Oswestry Disability Index ( $\triangle$ ODI), total blood loss, operation time and length of hospital stay. Review Manager 5.3 and Stata13.1 was used for the analysis of forest plots, heterogeneity, sensitivity and publication bias.

Results

17 studies were included ( $N=1562 ;$ PLIF, $n=835 ;$ TLIF, $n=727$ ). The pooled data showed PLIF had a higher complications ( $P=0.000)$, especially in nerve injury ( $p$ $=0.003)$ and dural tear $(p=0.005)$. PLIF required longer operation time $(p=0.004)$, more blood loss $(p=0.000)$ and hospital stays $(p=0.006)$. Surprisingly subgroup analysis showed there was significant difference in complications in patients under $55(p=0.000)$ and Asian countries $(p=0.000)$. No statistical difference was found between the two groups with regard to fusion rate $(p=0.593), \Delta$ VAS $(p=0.364)$ and $\triangle O D I(p=0.237)$.

Conclusions

This meta-analysis showed there were no significant difference in fusion rate, $\triangle$ VAS and $\triangle O D I$. However TLIF could reduce complications, especially nerve injury and dural tear. Besides, TLIF was associated with statistically significant less blood loss, shorter operation time and shorter length of hospital stay.

\section{Background}

Lumbar interbody fusion (LIF) is an established treatment for a range of spinal disorders including; degenerative pathologies, trauma, infection and neoplasia[1]. The procedure has been first described independently by Albee and Hibbs in 1911[2-3]. In 1944, Shinners and Hamby reported patients with disc protrusions could be treated by removal of the protruded disc and spine fusion[4]. In 1953 Cloward improved the traditional spine fusion by bone grafting and reported posterior lumbar interbody fusion (PLIF) [5]. This procedure can fully decompress the nerve and enable a stable three-column fixation with $360^{\circ}$ fusion and anterior support. The deficiency is the extensive dissection of the paravertebral soft tissue and a large incision. Lin improved this surgery preserving the integrity of facets in the 1970s[6]. Harms and Rolinge reported transforaminal lumbar interbody fusion (TLIF) in 1982[7]. Nerve decompression, bone graft and spine fusion were performed by unilateral approach in TLIF囚which could reduce surgical trauma. This procedure can preserve the posterior bony and soft tissue structures as much as possible. Its indications include all degenerative pathologies, such as broad-based disc prolapses, degenerate disc disease, recurrent disc herniation, pseudoarthrosis, and symptomatic spondylosis. Contraindications are similar to PLIF, including extensive epidural scaring, arachnoiditis, active infection and conjoined nerve roots (that may preclude access to the disc space) and osteoporotic patients.

Multiple studies have attempted to compare PLIF versus TLIF in terms of clinical and fusion outcomes. However, there is no consistent and definitive evidence for which one approach being superior to another. As a surgical procedure with a gentle learning curve, PLIF is more extensive than TLIF. The more lateral exposure to the interspace in TLIF as compared to PLIF gives it three distinct advantages over the latter, which are lesser neural retraction, a unilateral procedure and making revision surgeries less challenging[8]. It is still a question whether TLIF could be able to replace PLIF in lumbar operations.

Previous meta-analysis has some disadvantages, especially in the choice of statistical effect size and the subgroup division. We performed a systematic review of the literature and a meta-analysis on the effectiveness of both procedures in fusion rate, postoperative complications and other clinical outcomes in patients with LIF.

The innovation of this research lies in the followings. First, we used GRADE system to evaluate the clinical outcomes, making the conclusions more objective. Second, the subgroup analysis conducted some interesting results. There was statistically different in complications according to the age and countries, which were a totally new discovery.

\section{Materials And Methods}

\section{Search strategy}

The way to retrieve relevant studies is to use posterior lumbar interbody fusion, PLIF, transforaminal lumbar interbody fusion, TLIF, lumbar interbody fusion, spinal fusion, degenerative disc disease and lumbar degenerative diseases as key words with Boolean operators AND or OR in electronic databases including PubMed, Embase, Cochrane Library and Web of Science up to Feb 2020. The language of the literature was limited to Chinese and English. Two reviewers independently extracted relevant information from each eligible study. If there was disagreement, a third author was asked to join the discussion to resolve the controversy.

\section{Inclusion criteria}


Trials were included on condition that they met the PICOS (population, intervention, comparator, outcome, study design) criteria.

Population: patients underwent PLIF or TLIF for lumbar degenerative diseases

Intervention: transforaminal lumbar interbody fusion

Comparator: posterior lumbar interbody fusion

Outcomes: The primary outcomes are fusion rate and complications, such as screw broken or loose, cage migration, infection, dural tear and neural injury. The

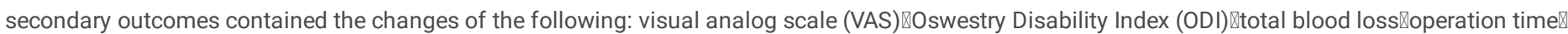
length of hospital stay

Study design: RCT and retrospective study

\section{Data extraction}

A standard data extraction form was used to collect the relevant data from included studies. Two reviewers collected available data from included studies independently, and any disagreement between the two reviewers was judged by a third reviewer. The relevant data included authors, published dates, intervention types, age, sample size, clinical diagnosis, duration of follow-up and reference type. Data on outcomes were obtained or statistics estimated from the data presented in tables or figures if no direct data were available from the article text.

\section{Methodological evaluation and quality assessment}

We used Cochrane Handbook to assess the quality of RCT and the Newcastle-Ottawa scale (NOS) to accomplish the methodological evaluation of nonRCTs[9-10]. According to the Cochrane Handbook for Systematic Reviews of Interventions, the methodological quality and basis of RCT were assessed as follows: randomization, allocation concealment, blind method, selective reporting, incomplete outcome data, and other bias. The NOS scale consists of eight items, categorized into three dimensions with a total of 9 points: selection of the study population (4 points), comparability between groups ( 2 points) and measurement of exposure factors (3 points). In general, if the total score of a single study reached or exceeded 6 points, it was considered a high-quality study; otherwise, it was a low-quality study. We used GRADE system to evaluate the level of the evidence and strength of recommendations for included outcomes[11]. Initially, RCTs were considered as high confidence in an estimate of effect and cohort studies were considered as low confidence. Reasons that may decrease the level of confidence include limitations, inconsistency, indirectness, and imprecision, and publication bias. Reasons that may raise the level of confidence include large effect, plausible confounding, dose-response. The GRADE evidence was divided into the following categories: (1) High-quality evidence, which indicated that further research was unlikely to change the confidence in an estimate of effect; (2) Moderate-quality evidence, which indicated that further research was likely to have an important impact on confidence in an estimate of effect and may change the estimate; (3) Low-quality evidence, which indicated that further research was likely to have an important impact on confidence in an estimate of effect and was likely to change the estimate; and (4) Very low-equality evidence, which indicated that we were very uncertain about the results.

\section{Statistical analysis and data synthesis}

Meta-analyses were performed with Review Manager Software for Windows (Version 5.3. Copenhagen: The Nordic Cochrane Centre, the Cochrane Collaboration, 2014) and Stata (Version 13.1). The standard mean difference (SMD) was used to assess continuous outcomes with a 95\% confidence interval (Cl). Odds ratio (OR) with a $95 \% \mathrm{Cl}$ were used to assess dichotomous outcomes. The inverse variance method was used to combine separate statistics. If $\mathrm{P}$ values were less than 0.05 , the results were considered statistically significant.

\section{Investigation of heterogeneity and publication bias}

Statistical heterogeneity of the included studies was evaluated using the chi-square test in accordance with the values of $\mathrm{P}$ and $\mathrm{I}^{2}$. If the values of $\mathrm{I}^{2}<50 \%$, the heterogeneity might not be important. A fixed-effects model was used to assess these outcomes. If $\mathrm{I}^{2}$ was between $50 \%$ and $100 \%$, it could represent substantial heterogeneity. We used random-effects model to evaluate these outcomes. Thresholds for the interpretation of $\mathrm{I}^{2}$ can be misleading, since the importance of inconsistency depends on several factors. Therefore, subgroup analysis or sensitivity analysis was performed to interpret the potential source of heterogeneity. Stata13.1 was used to evaluate the publication bias.

\section{Results}

\section{Study inclusion and baseline characteristics}

Finally, 17 studies were included in our meta-analysis[12-28]. One was RCT[15]; one was prospective cohort study[12]; others were retrospective studies. The Flow chart of the trial selection process was presented in Fig.1. Baseline characteristics of included trials are presented in Table 1.

\section{Risk of bias}

The results of Newcastle-Ottawa scale and GRADE analysis are presented in Table 1 and Table 2. The only RCT did not mention how the allocation concealment and blind method were used, so it was high risk[15].

\section{Primary outcomes}


Fusion rate. 17 studies reported fusion rate ( $N=987 ; \mathrm{PLIF}, \mathrm{n}=515 ; \mathrm{TLIF}, \mathrm{n}=472)$. The pooling data showed there was no significant difference between both groups (OR=0.832, 95\% Cl [0.423, 1.636], $\mathrm{P}=0.593$, Fig.2a)

Complications. 17 studies reported complications ( $\mathrm{N}=1562$; PLIF, $\mathrm{n}=835 ; \mathrm{TLIF}, \mathrm{n}=727)$. A pooled odds ratio for complications was 2.290 (95\%Cl [1.543, 3.399], $\mathrm{P}=0.000$, Fig.2b), indicating a significantly lower complication rate in TLIF, especially in nerve injury (OR=2.704, 95\%Cl [1.405, 5.204], $\mathrm{P}=0.003, \mathrm{Fig} .3 \mathrm{a})$ and dural tear $(\mathrm{OR}=2.213,95 \% \mathrm{Cl}[1.276,3.841], \mathrm{P}=0.005$, Fig.3b). There were no significant difference in other complications reported, such as screw broken or loose $(\mathrm{OR}=1.146,95 \% \mathrm{Cl}[0.444,2.955], \mathrm{P}=0.778$, Fig.3c), wound infection $(\mathrm{OR}=1.489,95 \% \mathrm{Cl}[0.760,2.917], \mathrm{P}=0.246$, Fig.3d) and cage migration (OR=2.177, $95 \% \mathrm{Cl}[0.442,10.732], \mathrm{P}=0.339$, Fig.3e). Subgroup analysis showed there was significant difference in complications for patients under 55 (OR=2.736, $95 \% \mathrm{Cl}$ $[1.775,4.217], P=0.000$, Fig.4a) and for Asian countries (OR=2.385, 95\% $\mathrm{Cl}[1.596,3.564], \mathrm{P}=0.000$, Fig.4b).

\section{Secondary outcomes}

$\Delta$ VAS. The improvement of VAS was reported in 8 studies (N=806; PLIF, $n=414 ;$ TLIF, $n=392)$. SMD was 0.064 (95\%Cl [-0.075, 0.203], P= 0.364, Fig.5a).

$\Delta$ ODI. The improvement of ODI was reported in 5 studies (N=353; PLIF, $n=174 ;$ TLIF, $n=179)$. SMD was $0.126(95 \% \mathrm{Cl}[-0.083,0.336], \mathrm{P}=0.237, \mathrm{Fig} .5 \mathrm{~b})$.

Total blood loss. The total blood loss was reported in 9 studies (N=693; PLIF, n=362; TLIF, n=331). SMD was 0.796 (95\%Cl [0.376, 1.217], P= 0.000, Fig.5c).

Operation time. The Operation time was reported in 9 studies (N=702; PLIF, n=385; TLIF, n=317). SMD was 0.618 (95\%Cl [0.202, 1.033], P= 0.004, Fig.5d).

Length of hospital stay. The Length of hospital stay was reported in 8 studies (N=693; PLIF, n=401; TLIF, n=292). SMD was 0.340 (95\%Cl [0.099, 0.581], P= 0.006 , Fig.5e).

\section{Sensitivity analysis and publication bias}

We performed the sensitivity analysis by the method of "trim and fill method" through packages of metatrim in Stata 13.1. We tested the publication bias of dichotomous variable with harbord, and continuous variable with egger by Stata 13.1.

Sensitivity analysis showed that the $95 \%$ confidence interval $(95 \% \mathrm{Cl})$ was no statistical difference in each outcome after "trim and fill method", indicating the pooled datas were steady. By harbord or egger test, if $\mathrm{P}$ Value was less than 0.05 , there was publication bias. Table 3 was the detailed results of sensitivity analysis and publication bias.

\section{Discussion}

Lumbar fusion is an accepted and effective technique for the treatment of lumbar degenerative disease[29]. Advancements in technique continue through the present day. PLIF is a original LIF approach, which involves the insertion of two cages through a bilateral approach. PLIF is considered as a standard surgical technique for lumbar degenerative diseases. However, the inevitable retraction of the thecal sac increases the risks of dural tear and nerve root injury. And excessive intraoperative dissection and retraction of the paraspinal musculature can lead to muscular injury, denervation and atrophy, and consequent chronic pain and weakness[30]. TLIF is a modification of PLIF, which can achieve interbody fusion with the insertion of cages only by the unilateral approach with less dural retraction. So TLIF is invasive than traditional PLIF. In this meta-analysis, we compared the common clinical outcomes between the PLIF and TLIF in patients undergoing lumbar interbody fusion, including fusion rate, complications, the improvement of VAS and ODI, blood loss, operation time, and the length of hospital stay.

The outcome was similar in fusion rate and improvement of VAS and ODI, indicating there is no significant difference in the primary goal of solid fusion and improvement of symptoms. The two approaches are effective.

Overall, TLIF performed better than the PLIF in complication prevention, especially in nerve injury and dural tear. According to age, subgroup analysis showed there was statistical difference in patients under 55 regarding to complications between the two operations, not in patients over 55 . A possible explanation for this might be that surgeons were more cautious about operating on older patients to reduce the risk of serious complications. According to nationality, subgroup analysis showed the PLIF complications are higher in Asia, however there was no significant difference in the complications between the two operations in the Occident. The disparity can be due to the differing experience of the operating surgeons with the technique. Surgeons might be more proficient and medical environment is better in the Occident.

With an ageing population, lumbar degenerative diseases often occur in the elderly underlying other diseases. Facing such a group with poor surgical tolerance, prone to intraoperative and postoperative complications and nosocomial infections, It is of great significance to reduce surgical trauma, shorten surgical time and reduce hospital stay. This study found that TLIF was exactly superior to PLIF in just above aspects. The dura sac and nerve root obstruct the approach to the disk space when PLIF is performed bilaterally, so the surgeon must perform the discectomy and cage insertion in a bilateral fashion, increasing the operative time and blood loss. In contrast, TLIF is performed in a unilateral approach to the disk space with a single cage, thus reducing operative time and blood loss[15].

Minimal access surgery has revolutionized most surgical disciplines and spine surgery is no exception. Minimally invasive transforaminal lumbar interbody fusion (MI-TLIF) was devised to reduce the approach-related morbidity of open TLIF and has flourished in the last decade[31]. It can significantly reduce blood loss[32]. However, there is a lack of multi-centre RCTs directly comparing open TLIF with MI-TLIF. 
There were some limitations in this meta-analysis. We initially planned to produce a review with only prospective studies. However, exploration of the literature indicated a limited availability of prospective studies. The included literature were mainly retrospective, only two prospective studies. Though the NOS scores

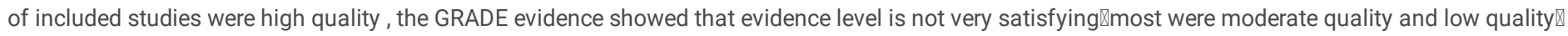
indicating that the follow-up research might affect the current conclusion. And the sample size is relatively small. So the pooling outcomes might be biased.

\section{Conclusions}

This meta-analysis showed there were no significant difference in fusion and the improvement of VAS and ODI. However TLIF could reduce complications, especially the nerve injury and dural tear. On the other hand, TLIF performed better in reducing intraoperative bleeding, shortening operative time and hospital stay. So TLIF might be a preferred choice for the older undergoing basic diseases. Considering the shortcomings of this study, more long-term follow-up RCTs and large sample are expected to provide further evidence of efficacy and safety between PLIF and TLIF in the treatment of lumbar degenerative diseases.

\section{Abbreviations}

posterior lumbar interbody fusion (PLIF); transforaminal lumbar interbody fusion (TLIF); population, intervention, comparator, outcome, study design (PICOS); visual analog scale $(\triangle \mathrm{VAS})$; Oswestry Disability Index $(\triangle \mathrm{ODI})$; Minimally invasive transforaminal lumbar interbody fusion (MI-TLIF); standard mean difference (SMD); confidence interval (Cl);Odds ratio (OR)

\section{Declarations}

\section{Ethics approval and consent to participate}

Not applicable

\section{Consent for publication}

Written informed consent was obtained from all patients for data

publication, including images

\section{Availability of data and materials}

All data generated or analysed during this study are included in this

published article

\section{Competing interests}

The authors declare that they have no competing interests in this section.

\section{Funding}

This study has been supported by grants from the Health Science and Technology of Tianjin Municipality (No.RC20204), Tianjin Institute of Orthopedics(No. 2019TJGYSKY03) and National Natural Science Foundation of China (No. 81871777,1177226).

\section{Declaration of Authors' contributions}

AT and $\mathrm{J} \mathrm{M} \mathrm{designed} \mathrm{research,} \mathrm{performed} \mathrm{research} \mathrm{,} \mathrm{and} \mathrm{wrote} \mathrm{the} \mathrm{paper} \mathrm{,X} \mathrm{M}$ was a major contributor in writing the manuscript and analyzed data, All authors read and approved the final manuscript.

\section{Acknowledgements}

None

\section{Authors' information}

${ }^{1}$ Orthopedic Research Institute, Tianjin Hospital, Tianjin University, Munan Street 122, Heping District, Tianjin 300050, P. R. China; ${ }^{2}$ Orthopedics Institute, Tianjin Hospital, Tianjin University, Jiefang Nan Road 406, Hexi District, Tianjin 300211,P. R. China;

\section{References}

[1] R.J. Mobbs, K. Phan, G. Malham, K. Seex, P.J. Rao, Lumbar interbody fusion: techniques, indications and comparison of interbody fusion options including PLIF, TLIF, MI-TLIF, OLIF/ATP, LLIF and ALIF.J Spine Surg.2015; 1:2-18.

[2] F.H. ALBEE, TRANSPLANTATION OF A PORTION OF THE TIBIA INTO THE SPINE FOR POTT'S DISEASE: A PRELIMINARY REPORT. Journal of the American Medical Association.1911; LVII : 885-886. 
[3] R.A. Hibbs, An operation for progressive spinal deformities: a preliminary report of three cases from the service of the orthopaedic hospital. Clin Orthop Relat Res.2007; $460: 17-20$.

[4] B.M. Shinners, W.B. Hamby, The Results of Surgical Removal of Protruded Lumbar Intervertebral Discs.J. Neurosurgery.1944; 1:117-122.

[5] R.B. CLOWARD, The treatment of ruptured lumbar intervertebral discs by vertebral body fusion. I. Indications, operative technique, after care.J NEUROSURG. $1953 ; 10: 154-168$.

[6] P.M. Lin, A technical modification of Cloward's posterior lumbar interbody fusion.NEUROSURGERY.1977; $1: 118-124$.

[7] J. Harms, H. Rolinger, [A one-stager procedure in operative treatment of spondylolistheses: dorsal traction-reposition and anterior fusion (author's transl)].Z Orthop Ihre Grenzgeb.1982;120 : 343-347.

[8] J.D. Schwender, L.T. Holly, D.P. Rouben, K.T. Foley, Minimally invasive transforaminal lumbar interbody fusion (TLIF): technical feasibility and initial results. J SPINAL DISORD TECH.2005; 18 Suppl : S1-6.

[9] A. Stang, Critical evaluation of the Newcastle-Ottawa scale for the assessment of the quality of nonrandomized studies in meta-analyses.EUR J EPIDEMIOL.2010; 25 : 603-605.

[10] M. Cumpston, T. Li, M.J. Page, J. Chandler, V.A. Welch, J.P. Higgins, J. Thomas, Updated guidance for trusted systematic reviews: a new edition of the Cochrane Handbook for Systematic Reviews of Interventions.Cochrane Database Syst Rev.2019;10 : ED000142.

[11] G. Guyatt, A.D. Oxman, E.A. Akl, R. Kunz, G. Vist, J. Brozek, S. Norris, Y. Falck-Ytter, P. Glasziou, H. DeBeer, R. Jaeschke, D. Rind, J. Meerpohl, P. Dahm, H.J. Schunemann, GRADE guidelines: 1. Introduction-GRADE evidence profiles and summary of findings tables. J CLIN EPIDEMIOL.2011; 64:383-394.

[12] X. Cheng, K. Zhang, X. Sun, C. Zhao, H. Li, B. Ni, J. Zhao, Clinical and radiographic outcomes of bilateral decompression via a unilateral approach with transforaminal lumbar interbody fusion for degenerative lumbar spondylolisthesis with stenosis. SPINE J.2017; 17 : $1127-1133$.

[13] N. Lee, K.N. Kim, S. Yi, Y. Ha, D.A. Shin, D.H. Yoon, K.S. Kim, Comparison of Outcomes of Anterior, Posterior, and Transforaminal Lumbar Interbody Fusion Surgery at a Single Lumbar Level with Degenerative Spinal Disease.WORLD NEUROSURG.2017;101:216-226.

[14] L. Li, Y. Liu, P. Zhang, T. Lei, J. Li, Y. Shen, Comparison of posterior lumbar interbody fusion with transforaminal lumbar interbody fusion for treatment of recurrent lumbar disc herniation: A retrospective study. J INT MED RES.2016; 44 :1424-1429.

[15] E.Z. Yang, J.G. Xu, X.K. Liu, G.Y. Jin, W. Xiao, B.F. Zeng, X.F. Lian, An RCT study comparing the clinical and radiological outcomes with the use of PLIF or TLIF after instrumented reduction in adult isthmic spondylolisthesis. EUR SPINE J.2016; 25 :1587-1594.

[16] J. Liu, H. Deng, X. Long, X. Chen, R. Xu, Z. Liu, A comparative study of perioperative complications between transforaminal versus posterior lumbar interbody fusion in degenerative lumbar spondylolisthesis. EUR SPINE J. 2016;25:1575-1580.

[17] K. Asil, C. Yaldiz, Retrospective Comparison of Radiological and Clinical Outcomes of PLIF and TLIF Techniques in Patients Who Underwent Lumbar Spinal Posterior Stabilization.Medicine (Baltimore).2016;95:e3235.

[18] S. Han, Q. Xiao, G. Zhu, J. Dai, X. Tang, H. Sun, Comparison between transforaminal lumbar interbody fusion and posterior lumbar interbody fusion in treatment of lumbar spondylolisthesis.INT J CLIN EXP MED.2016;9:3932-3938.

[19] S.L. de Kunder, K. Rijkers, W.L.W. van Hemert, P.C.P.H. Willems, P.M.P. ter Laak, H. van Santbrink, Transforaminal versus posterior lumbar interbody fusion as operative treatment of lumbar spondylolisthesis, a retrospective case series, Interdisciplinary Neurosurgery: Advanced Techniques and Case Management.2016; $5: 64-68$.

[20] S. Fariborz, M. Gharedaghi, A.F. Khosravi, M. Samini, Comparison of Results of 4 Methods of Surgery in Grade 1 Lumbosacral Spondylolisthesis. Neurosurgery Quarterly.2016;26: 1.

[21] B.M. Al, Z.M. Audat, M.Z. Allouh, Analytical comparison study of the clinical and radiological outcome of spine fixation using posterolateral, posterior lumber interbody and transforaminal lumber interbody spinal fixation techniques to treat lumber spine degenerative disc disease. Scoliosis.2015; $10: 17$.

[22] N. Sakeb, K. Ahsan, Comparison of the early results of transforaminal lumbar interbody fusion and posterior lumbar interbody fusion in symptomatic lumbar instability.INDIAN J ORTHOP.2013; 47 : 255-263.

[23] Z. Audat, O. Moutasem, K. Yousef, B. Mohammad, Comparison of clinical and radiological results of posterolateral fusion, posterior lumbar interbody fusion and transforaminal lumbar interbody fusion techniques in the treatment of degenerative lumbar spine. Singapore Med J.2012; 53: 183-187.

[24] V.A. Mehta, M.J. McGirt, A.G. Garces, S.L. Parker, D.M. Sciubba, A. Bydon, J.P. Wolinsky, Z.L. Gokaslan, T.F. Witham, Trans-foraminal versus posterior lumbar interbody fusion: comparison of surgical morbidity.NEUROL RES. 2011;33 : 38-42.

[25] X. Zhuo, J. Hu, B. Li, H. Sun, Y. Chen, Z. Hu, [Comparative study of treating recurrent lumbar disc protrusion by three different surgical procedures]. Zhongguo Xiu Fu Chong Jian Wai Ke Za Zhi.2009; 23 :1422-1426. 
[26] D.L. Yan, F.X. Pei, J. Li, C.L. Soo, Comparative study of PILF and TLIF treatment in adult degenerative spondylolisthesis. EUR SPINE J.2008; 17 :1311-1316.

[27] M.D. Jae-Sung Park, M.D. Young-Baeg Kim, M.D. Hyun-Jong Hong, M.D. Sung-Nam Hwang, Comparison between Posterior and Transforaminal Approaches for Lumbar Interbody Fusion. J KOREAN NEUROSURG S.2005;37:340-344.

[28] S.C. Humphreys, S.D. Hodges, A.G. Patwardhan, J.C. Eck, R.B. Murphy, L.A. Covington, Comparison of posterior and transforaminal approaches to lumbar interbody fusion. Spine (Phila Pa 1976).2001; $26: 567-571$.

[29] P.C. Reid, S. Morr, M.G. Kaiser, State of the union: a review of lumbar fusion indications and techniques for degenerative spine disease. J Neurosurg Spine.2019; $31: 1-14$.

[30] Z.J. Hu, X.Q. Fang, Z.J. Zhou, J.Y. Wang, F.D. Zhao, S.W. Fan, Effect and possible mechanism of muscle-splitting approach on multifidus muscle injury and atrophy after posterior lumbar spine surgery. J BONE JOINT SURG AM. 2013;95 :e192(1-9).

[31] B. Garg, N. Mehta, Minimally invasive transforaminal lumbar interbody fusion (MI-TLIF): A review of indications, technique, results and complications.J Clin Orthop Trauma. 2019;10:S156-S162.

[32] A. Li, X. Li, Y. Zhong, Is minimally invasive superior than open transforaminal lumbar interbody fusion for single-level degenerative lumbar diseases: a meta-analysis.J ORTHOP SURG RES.2018; $13: 241$.

\section{Tables}

Table 1 Characteristics of included studies 


\begin{tabular}{|c|c|c|c|c|c|c|c|c|c|c|c|c|}
\hline \multirow{2}{*}{$\begin{array}{l}\text { Study } \\
\text { (year) }\end{array}$} & \multicolumn{2}{|c|}{$\begin{array}{l}\text { Number of } \\
\text { patients(n) }\end{array}$} & \multicolumn{2}{|c|}{ Gender(M/F) } & & & \multicolumn{2}{|c|}{$\begin{array}{l}\text { Follow-up } \\
\text { (months) }\end{array}$} & \multirow[t]{2}{*}{ Country } & \multirow[t]{2}{*}{ Diagnosis } & \multirow[t]{2}{*}{$\begin{array}{l}\text { Reference } \\
\text { type }\end{array}$} & \multirow[t]{2}{*}{ NOS } \\
\hline & PLIF & TLIF & PLIF & TLIF & PLIF & TLIF & PLIF & TLIF & & & & \\
\hline Al 2015 & 40 & 50 & $12 / 28$ & $19 / 31$ & 51.6 & 49.5 & 60 & 60 & Jordan & $\begin{array}{l}\text { Degenerative disc } \\
\text { disease }\end{array}$ & Retrospective & 8 \\
\hline Asil 2016 & 41 & 33 & $12 / 29$ & $8 / 25$ & $55.76 \pm 7.78$ & $53.76 \pm 7.95$ & 12 & 12 & Turkey & $\begin{array}{l}\text { Degenerative } \\
\text { narrow spinal } \\
\text { canal } \\
\text { and lumbar } \\
\text { spondylolisthesis }\end{array}$ & Retrospective & 8 \\
\hline $\begin{array}{l}\text { Audat } \\
2012\end{array}$ & 27 & 37 & $6 / 21$ & $14 / 23$ & $50.6 \pm 13.1$ & $45.8 \pm 12.3$ & 36 & 36 & Jordan & $\begin{array}{l}\text { Degenerative disc } \\
\text { disease }\end{array}$ & Retrospective & 8 \\
\hline $\begin{array}{l}\text { Cheng } \\
2017\end{array}$ & 40 & 43 & $19 / 21$ & $18 / 25$ & $58.5 \pm 8.1$ & $59.7 \pm 8.4$ & 24 & 24 & China & $\begin{array}{l}\text { Degenerative } \\
\text { lumbar } \\
\text { spondylolisthesis }\end{array}$ & $\begin{array}{l}\text { prospective } \\
\text { cohort }\end{array}$ & 8 \\
\hline $\begin{array}{l}\text { de Kunder } \\
2016\end{array}$ & 48 & 48 & $23 / 25$ & $17 / 31$ & 58 & 58 & 12 & 12 & Netherlands & $\begin{array}{l}\text { Spondylolisthesis } \\
\text { (isthmic or } \\
\text { degenerative) }\end{array}$ & Retrospective & 8 \\
\hline $\begin{array}{l}\text { Fariborz } \\
2016\end{array}$ & 30 & 30 & $18 / 12$ & $15 / 15$ & $30-40$ & $30-40$ & 12 & 12 & Iran & $\begin{array}{l}\text { Disk herniation or } \\
\text { lumbar canal } \\
\text { stenosis }\end{array}$ & Retrospective & 8 \\
\hline Han 2016 & 26 & 36 & $16 / 10$ & $20 / 16$ & $57.31 \pm 9.04$ & $59.69 \pm 8$ & 19 & 21 & China & $\begin{array}{l}\text { Lumbar } \\
\text { spondylolisthesis }\end{array}$ & Retrospective & 8 \\
\hline $\begin{array}{l}\text { Humphreys } \\
2001\end{array}$ & 34 & 40 & $22 / 12$ & $20 / 20$ & 40 & 41 & 13 & 13 & USA & $\begin{array}{l}\text { Degenerative disc } \\
\text { disease, central } \\
\text { disc herniation } \\
\text { and } \\
\text { spondylolisthesis }\end{array}$ & Retrospective & 8 \\
\hline Lee 2017 & 30 & 21 & $7 / 23$ & $5 / 16$ & $56.5 \pm 13.1$ & $59.4 \pm 13.0$ & 19 & 23 & Korea & $\begin{array}{l}\text { Degenerative } \\
\text { spinal stenosis } \\
\text { and spondylolytic } \\
\text { spondylolisthesis }\end{array}$ & Retrospective & 8 \\
\hline Li 2016 & 26 & 25 & $17 / 9$ & $18 / 7$ & $43.8 \pm 12.1$ & $44.5 \pm 12.4$ & 43 & 43 & China & $\begin{array}{l}\text { Recurrent lumbar } \\
\text { disc herniation }\end{array}$ & Retrospective & 8 \\
\hline Liu 2016 & 125 & 101 & $40 / 85$ & $42 / 59$ & $55.1 \pm 10.2$ & $54.1 \pm 12.9$ & NG & NG & China & $\begin{array}{l}\text { Degenerative } \\
\text { lumbar } \\
\text { spondylolisthesis }\end{array}$ & Retrospective & 8 \\
\hline $\begin{array}{l}\text { Mehta } \\
2011\end{array}$ & 76 & 43 & $34 / 42$ & $16 / 27$ & $48.6 \pm 12.3$ & $48.1 \pm 14.6$ & 24 & 24 & USA & $\begin{array}{l}\text { Degenerative disc } \\
\text { disease and } \\
\text { spondylolithesis }\end{array}$ & Retrospective & 8 \\
\hline Park 2005 & 99 & 29 & $43 / 56$ & $10 / 19$ & 54 & 57 & 20.2 & 10.4 & Korea & $\begin{array}{l}\text { Spinal stenosis } \\
\text { and instability }\end{array}$ & Retrospective & 8 \\
\hline $\begin{array}{l}\text { Sakeb } \\
2013\end{array}$ & 52 & 50 & $11 / 41$ & $14 / 36$ & $46 \pm 5.9$ & $49 \pm 6.9$ & 12 & 12 & Bangladesh & Lumbar instability & Retrospective & 8 \\
\hline Yan 2008 & 85 & 91 & $41 / 44$ & $46 / 45$ & $58.7 \pm 9.6$ & $57.5 \pm 11.2$ & 29.5 & 29.6 & China & $\begin{array}{l}\text { Degenerative } \\
\text { spondylolisthesis }\end{array}$ & Retrospective & 8 \\
\hline Yang 2016 & 34 & 32 & $14 / 20$ & $13 / 19$ & 42.7 & 44.1 & 30.5 & 30.5 & China & $\begin{array}{l}\text { Isthmic } \\
\text { spondylolisthesis }\end{array}$ & RCT & 8 \\
\hline Zhuo 2009 & 22 & 18 & $14 / 8$ & $13 / 5$ & 41 & 43 & 63 & 73 & China & $\begin{array}{l}\text { Recurrent lumbar } \\
\text { disc protrusio }\end{array}$ & Retrospective & 8 \\
\hline
\end{tabular}

Table 2 The GRADE evidence quality for each outcome 
Outcomes

\begin{tabular}{|c|c|c|c|c|c|c|c|c|c|c|}
\hline Fusion rate & $\begin{array}{l}\text { observational } \\
\text { studies }\end{array}$ & no & no & no & no & unlikely & no & no & no & $\begin{array}{l}\oplus \oplus \Theta \epsilon \\
\text { Low }\end{array}$ \\
\hline Complications & $\begin{array}{l}\text { observational } \\
\text { studies }\end{array}$ & no & no & no & no & likely & large & no & no & $\begin{array}{l}\oplus \oplus \Theta \epsilon \\
\text { Low }\end{array}$ \\
\hline Nerve injury & $\begin{array}{l}\text { observational } \\
\text { studies }\end{array}$ & no & no & no & no & likely & large & no & no & $\begin{array}{l}\oplus \oplus \Theta \epsilon \\
\text { Low }\end{array}$ \\
\hline Screws & $\begin{array}{l}\text { observational } \\
\text { studies }\end{array}$ & no & no & no & no & unlikely & no & no & no & $\begin{array}{l}\oplus \oplus \Theta \epsilon \\
\text { Low }\end{array}$ \\
\hline Infection & $\begin{array}{l}\text { observational } \\
\text { studies }\end{array}$ & no & no & no & no & likely & no & no & no & $\begin{array}{l}\oplus \Theta \Theta \epsilon \\
\text { Very L }\end{array}$ \\
\hline $\begin{array}{l}\text { Cage } \\
\text { migration }\end{array}$ & $\begin{array}{l}\text { observational } \\
\text { studies }\end{array}$ & no & no & no & no & unlikely & large & no & no & $\begin{array}{l}\oplus \oplus \oplus \epsilon \\
\text { moder }\end{array}$ \\
\hline Drual tear & $\begin{array}{l}\text { observational } \\
\text { studies }\end{array}$ & no & no & no & no & unlikely & large & no & no & $\begin{array}{l}\oplus \oplus \oplus \epsilon \\
\text { moder }\end{array}$ \\
\hline Revision & $\begin{array}{l}\text { observational } \\
\text { studies }\end{array}$ & no & no & no & no & unlikely & no & no & no & $\begin{array}{l}\oplus \oplus \Theta \epsilon \\
\text { Low }\end{array}$ \\
\hline$\triangle \mathrm{VAS}$ & $\begin{array}{l}\text { observational } \\
\text { studies }\end{array}$ & no & no & no & no & unlikely & no & no & no & $\begin{array}{l}\oplus \oplus \Theta \epsilon \\
\text { low }\end{array}$ \\
\hline$\triangle \mathrm{ODI}$ & $\begin{array}{l}\text { observational } \\
\text { studies }\end{array}$ & no & no & no & no & unlikely & no & no & no & $\begin{array}{l}\oplus \oplus \Theta \epsilon \\
\text { low }\end{array}$ \\
\hline $\begin{array}{l}\text { Total blood } \\
\text { loss }\end{array}$ & $\begin{array}{l}\text { observational } \\
\text { studies }\end{array}$ & no & no & no & no & unlikely & large & no & no & $\begin{array}{l}\oplus \oplus \oplus \epsilon \\
\text { moder }\end{array}$ \\
\hline $\begin{array}{l}\text { Operation } \\
\text { time }\end{array}$ & $\begin{array}{l}\text { observational } \\
\text { studies }\end{array}$ & no & no & no & no & unlikely & large & no & no & $\begin{array}{l}\oplus \oplus \oplus \epsilon \\
\text { moder }\end{array}$ \\
\hline $\begin{array}{l}\text { Length of } \\
\text { hospital stay }\end{array}$ & $\begin{array}{l}\text { observational } \\
\text { studies }\end{array}$ & no & no & no & no & unlikely & large & no & no & $\begin{array}{l}\oplus \oplus \oplus \epsilon \\
\text { moder }\end{array}$ \\
\hline
\end{tabular}

High quality: Further research is very unlikely to change our confidence in the estimate of effect.

Moderate quality: Further research is likely to have an important impact on our confidence in the estimate of effect and may change the estimate.

Low quality: Further research is very likely to have an important impact on our confidence in the estimate of effect and is likely to change the estimate.

Very low quality: We are very uncertain about the estimate.

Table 3 Sensitivity analysis and publication bias

\begin{tabular}{|c|c|c|c|c|c|c|c|c|c|}
\hline $\begin{array}{l}\text { Stability } \\
\text { test }\end{array}$ & Fusion rate & Complications & Nerve injury & $\begin{array}{l}\text { Screw } \\
\text { broken } \\
\text { or loose }\end{array}$ & $\begin{array}{l}\text { Wound } \\
\text { infection }\end{array}$ & $\begin{array}{l}\text { Cage } \\
\text { migration }\end{array}$ & Dural tear & $\triangle \mathrm{VAS}$ & $\triangle O D I$ \\
\hline $\begin{array}{l}95 \% \mathrm{Cl} \\
\text { Before } \\
\text { metatrim }\end{array}$ & $(0.423,1.636)$ & $(1.543,3.399)$ & $(1.405,5.204)$ & $(0.444,2.955)$ & $(0.760,2.917)$ & $(0.442,10.73)$ & $(1.276,3.841)$ & $(-0.075,0.203)$ & $(-0.083$, \\
\hline $\begin{array}{l}95 \% \mathrm{Cl} \\
\text { After } \\
\text { metatrim }\end{array}$ & $(0.423,1.636)$ & $(1.366,3.124)$ & $(1.405,5.204)$ & $(0.444,2.955)$ & $(0.672,2.375)$ & $(0.442,10.73)$ & $(1.194,3.623)$ & $(-0.075,0.203)$ & $(-0.083$, \\
\hline $\begin{array}{l}\text { Published } \\
\text { bais } \\
\text { (P Value) }\end{array}$ & 0.560 & 0.001 & 0.007 & 0.055 & 0.001 & 0.094 & 0.120 & 0.425 & 0.742 \\
\hline
\end{tabular}




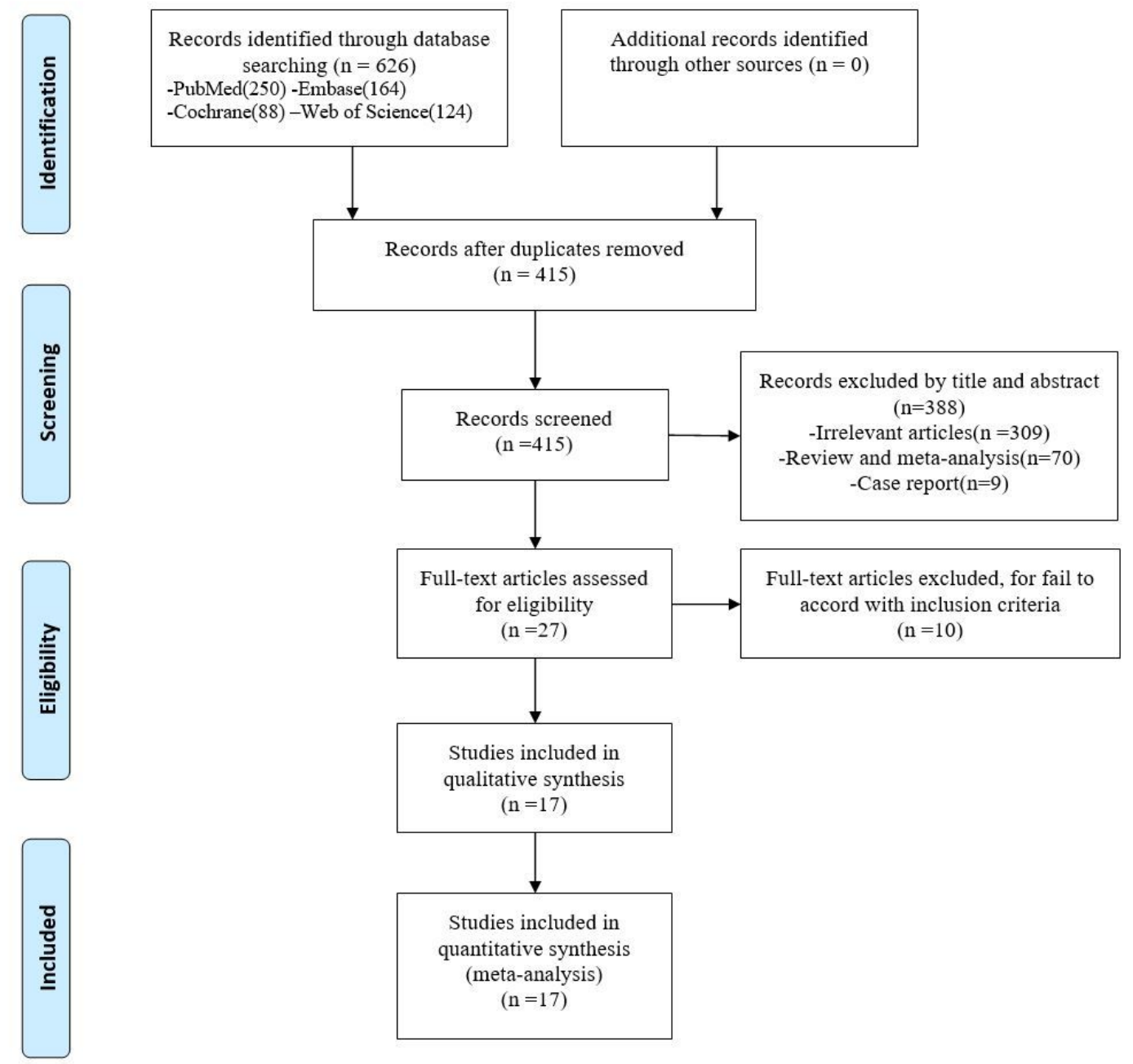

\section{Figure 1}

The Flow chart of the trial selection process was presented 


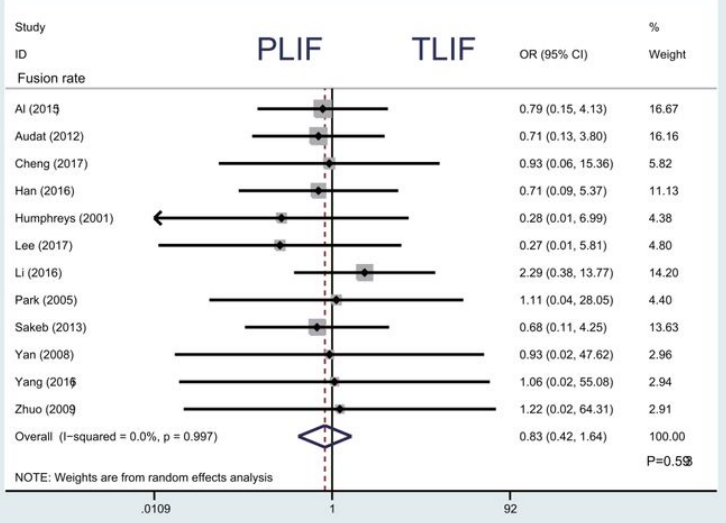

b

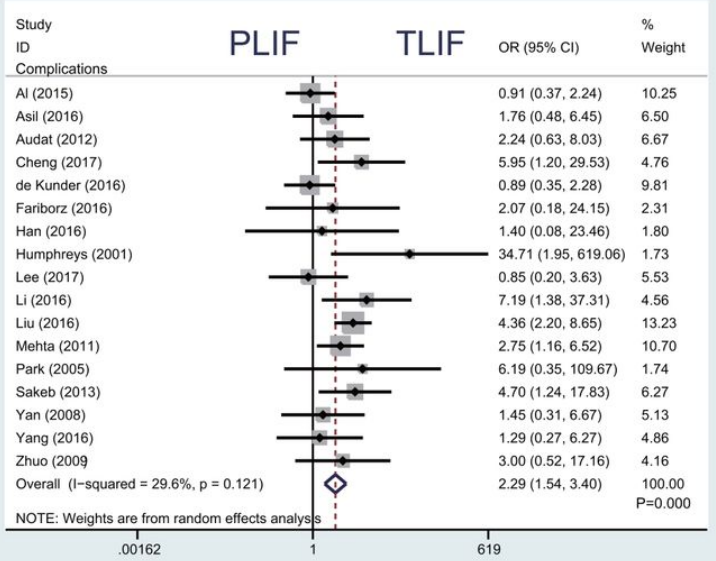

\section{Figure 2}

studies reported fusion rate $(N=987 ; P L I F, n=515 ; T L I F, n=472)$. The pooling data showed there was no significant difference between both groups $(O R=0.832$, $95 \% \mathrm{Cl}[0.423,1.636], \mathrm{P}=0.593$, 


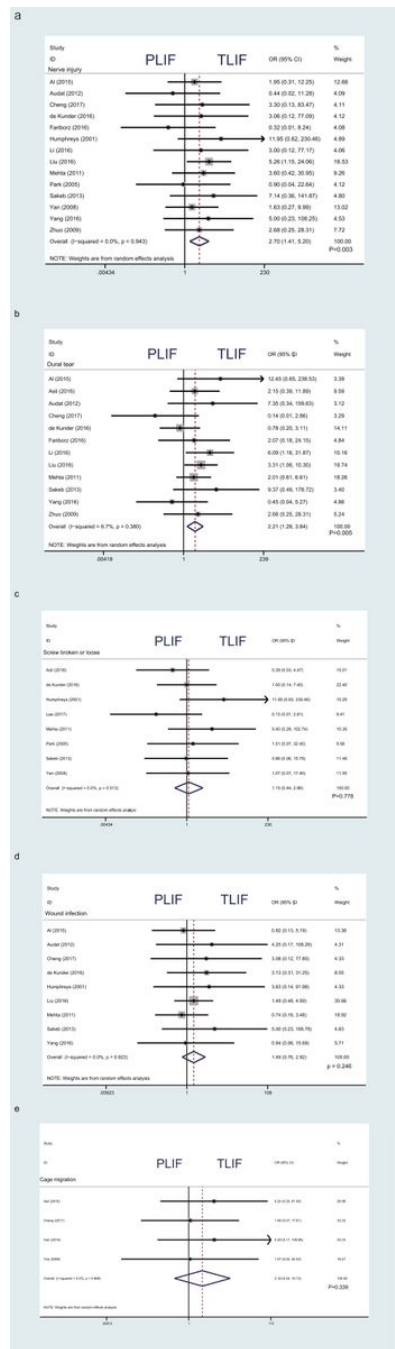

\section{Figure 3}

studies reported complications ( $N=1562 ; \mathrm{PLIF}, \mathrm{n}=835 ; \mathrm{TLIF}, \mathrm{n}=727)$. A pooled odds ratio for complications was 2.290 (95\%Cl [1.543, 3.399], $\mathrm{P}=0.000, \mathrm{Fig} .2 \mathrm{~b})$, indicating a significantly lower complication rate in TLIF, especially in nerve injury $(\mathrm{OR}=2.704,95 \% \mathrm{Cl}[1.405,5.204], \mathrm{P}=0.003$, ) and dural tear $(\mathrm{OR}=2.213,95 \% \mathrm{Cl}$ $[1.276,3.841], P=0.005$,$) .$ 


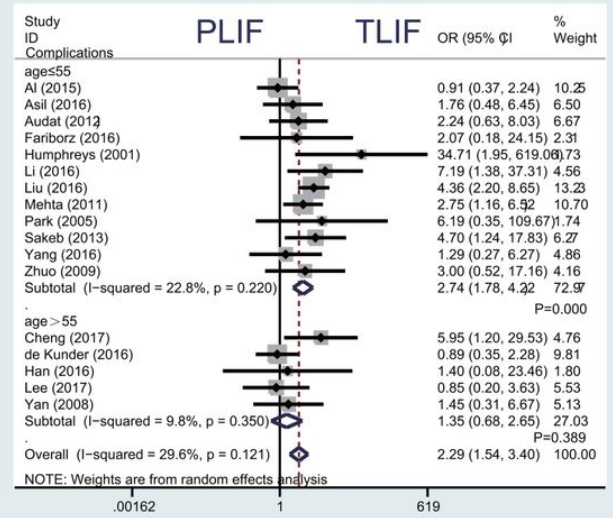

b

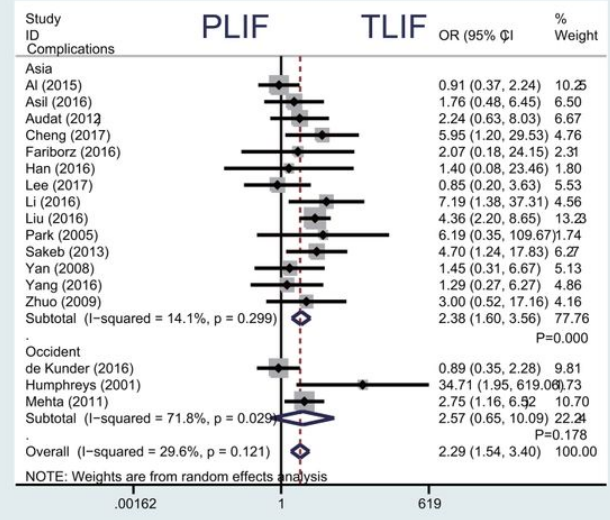

\section{Figure 4}

Subgroup analysis showed there was significant difference in complications for patients under $55(\mathrm{OR}=2.736,95 \% \mathrm{Cl}[1.775,4.217], \mathrm{P}=0.000$,) and for $\mathrm{Asian}$ countries $(\mathrm{OR}=2.385,95 \% \mathrm{Cl}[1.596,3.564], \mathrm{P}=0.000$,$) .$ 

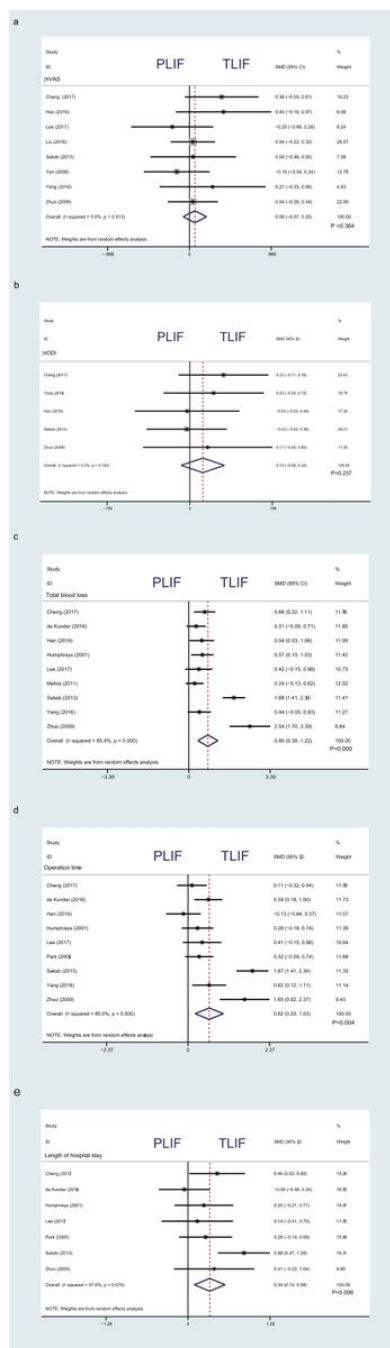

Figure 5

$\triangle$ VAS. The improvement of VAS was reported in 8 studies ( $N=806 ; \mathrm{PLIF}, \mathrm{n}=414 ; \mathrm{TLIF}, \mathrm{n}=392)$. SMD was $0.064(95 \% \mathrm{Cl}[-0.075,0.203], \mathrm{P}=0.364$,). 